Supporting Information for

\title{
Mechanistic Studies of Hangman Salophen-Mediated Activation of O-O Bonds
}

\author{
Shih-Yuan Liu, ${ }^{\dagger}$ Jake D. Soper, ${ }^{\dagger}$ Jenny Y. Yang, ${ }^{\dagger}$ Elena V. Rybak-Akimova ${ }^{\ddagger}$ and Daniel G. \\ Nocera*,† \\ Department of Chemistry, 6-335, Massachusetts Institute of Technology, 77 Massachusetts Avenue, \\ Cambridge, MA 02139-4307 Department of Chemistry, Tufts University, 62 Talbot Avenue, Medford, \\ MA 02155
}

Index

Page

Synthesis of Nitridomanganese(V) Salophen Complex Mn(N)-SalophOMe

Synthesis of EHSX-Mn-SalophOMe

Stopped-Flow UV-VIS Kinetic Measurements

S6-S7

Experimental Protocol for Hydrogen Peroxide Disproportionation Reactions

UV-VIS Kinetics of HSX-Mn-SalophOMe Decomposition in the Presence of $\mathrm{H}_{2} \mathrm{O}_{2}$

Structural Data for Mn(N)-SalophOMe

S10-S19 


\section{General Methods}

Dichloromethane and diethylether were passed through a neutral alumina column under argon before usage. Methyl alcohol (Aldrich; anhydrous), ethyl alcohol (Aldrich; anhydrous), water (EM Science), and hydrogen peroxide (Alfa Aesar, 30\%) were used as received. The purchased hydrogen peroxide was volumetrically determined to be $10.4 \mathrm{M}(32 \%)$ via its decomposition to oxygen gas over manganese dioxide. 1,2-Phenylenediamine (Aldrich, flakes), ammonium hydroxide (28\% $\mathrm{NH}_{3}$ in water, Aldrich), $\mathrm{NaOCl}$ (13\% in water, Alfa Aesar) were used as received. 3-tert-Butyl-2-hydroxy-5-methoxy-benzaldehyde ${ }^{1}$ was prepared according to literature procedures. HSX-Mn-SalophOMe (1) ${ }^{2}$ was prepared according to literature procedures and recrystallized from $\mathrm{CH}_{2} \mathrm{Cl}_{2} / \mathrm{Et}_{2} \mathrm{O}$ before usage.

${ }^{1} \mathrm{H}-\mathrm{NMR}$ spectra were recorded at the MIT Department of Chemistry Instrumentation Facility (DCIF) on a Varian Inova 500 spectrometer. ${ }^{1} \mathrm{H}$ NMR chemical shifts are quoted in ppm relative to tetramethylsilane and spectra have been internally calibrated to the monoprotio impurity of the deuterated solvent used. Spectra were recorded at $20^{\circ} \mathrm{C}$ unless otherwise stated.

UV-visible absorption spectra were recorded on a Spectral Instruments 440 spectrophotometer. IR absorption spectra were recorded on a Perkin-Elmer 2000 FT-IR spectrophotometer.

\section{Synthesis and Characterization of Nitridomanganese(V) Salophen Complex}

Synthesis of $\mathbf{H}_{2}$-SalophOMe. A vial containing a stirbar was charged with 1,2phenylenediamine (108 mg, $1.00 \mathrm{mmol})$ and 3-tert-butyl-2-hydroxy-5-methoxybenzaldehyde (416 mg, $2.00 \mathrm{mmol})$. Ethanol $(4.0 \mathrm{~mL})$ was added, the vial was sealed with a Teflon cap, and the reaction mixture was stirred at $100{ }^{\circ} \mathrm{C}$ for $21 \mathrm{~h}$. The desired product precipitated out of solution as a red-orange solid and was collected on a glass frit after filtering and copious washings with EtOH (369 mg, 76\%).

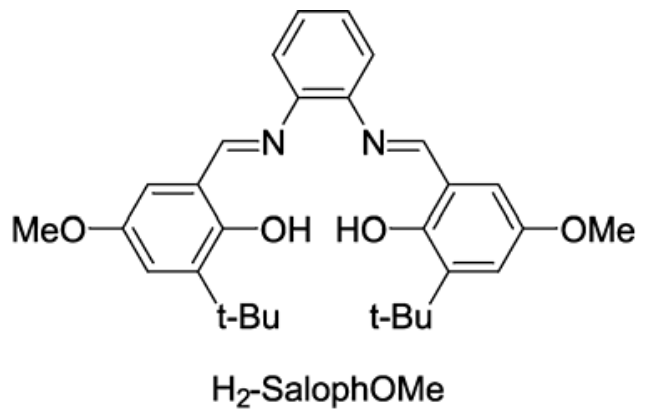

${ }^{1} \mathrm{H}$ NMR (500 MHz, $\left.\mathrm{CD}_{2} \mathrm{Cl}_{2}\right): \delta 13.42(\mathrm{~s}, 2 \mathrm{H}), 8.66(\mathrm{~s}, 2 \mathrm{H}), 7.37(\mathrm{dd}, J=5.5 \mathrm{~Hz}, 3.0 \mathrm{~Hz}, 2 \mathrm{H})$, 7.29 (dd, $J=5.5 \mathrm{~Hz}, 3.0 \mathrm{~Hz}, 2 \mathrm{H}), 7.03$ (d, $J=3.0 \mathrm{~Hz}, 2 \mathrm{H}), 6.77$ (d, $J=3.0 \mathrm{~Hz}, 2 \mathrm{H}), 3.78$ (s, 6H), $1.42(\mathrm{~s}, 18 \mathrm{H}) .{ }^{13} \mathrm{C}$ NMR $\left(125 \mathrm{MHz}, \mathrm{CD}_{2} \mathrm{Cl}_{2}\right): \delta 164.8,155.8,152.1,143.0,139.8,128.2,120.1$

(1) Larrow, J. R.; Jacobsen, E. N.; Gao, Y.; Hong, Y.; Nie, X.; Zepp, C. M. J. Org. Chem. 1994, 59, 1939-42.

(2) Liu, S.-Y.; Nocera, D. G. J. Am. Chem. Soc. 2005, 127, 5278-5279. 
(2x), 119.0, 112.5, 56.2, 35.5, 29.5. FTIR (thin film) 2954, 1617, 1595, 1571, 1448, 1428, 1333, 1206, 1150, 1060. HRMS (ESI) Calcd for $\mathrm{C}_{30} \mathrm{H}_{36} \mathrm{~N}_{2} \mathrm{O}_{4}: \mathrm{M}+\mathrm{Na}^{+}=511.2567$. Found 511.2584.

Synthesis of Mn-SalophOMe (3). A vial containing a stirbar was charged with $\mathbf{H}_{2}$-SalophOMe $(70.0 \mathrm{mg}, 0.143 \mathrm{mmol})$ and $\mathrm{Mn}(\mathrm{OAc})_{2} \bullet 4 \mathrm{H}_{2} \mathrm{O}(39.0 \mathrm{mg}, 0.158 \mathrm{mmol})$. Ethanol $(1.6 \mathrm{~mL})$ was added, and the reaction mixture was stirred at room temperature for $21 \mathrm{~h}$. The dark brown reaction mixture was diluted with $\mathrm{CH}_{2} \mathrm{Cl}_{2}$. The organic extract was washed with brine. The desired product precipitated out of solution as a brown solid and was collected on a glass frit after filtering and copious washings with $\mathrm{Et}_{2} \mathrm{O}$ (72 mg, 87\%).

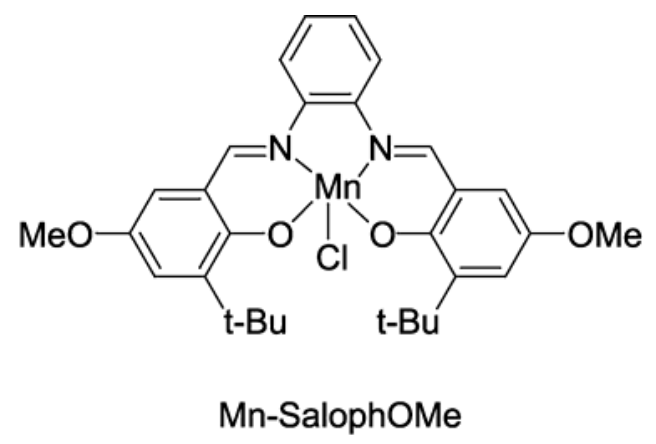

HRMS (ESI) Calcd for $\mathrm{C}_{30} \mathrm{H}_{34} \mathrm{~N}_{2} \mathrm{O}_{4} \mathrm{MnCl}: \mathrm{M}-\mathrm{Cl}^{+}=541.1894$. Found 541.1870.

Synthesis of Mn(N)-SalophOMe. A vial containing a stirbar was charged with MnSalophOMe (25 mg, $0.043 \mathrm{mmol})$ in $0.6 \mathrm{~mL} \mathrm{MeOH}$. Under vigorous stirring at room temperature, ammonium hydroxide $(41 \mu \mathrm{L}, 0.65 \mathrm{mmol} ; 16 \mathrm{M}$ in water) was added dropwise followed by $\mathrm{NaOCl}\left(130 \mu \mathrm{L}, 0.26 \mathrm{mmol} ; 2.0 \mathrm{M}\right.$ in water). $\mathrm{CH}_{2} \mathrm{Cl}_{2}$ was added, followed by water to form a biphasic mixture. The brown organic phase was washed with water $(\times 3)$, dried over $\mathrm{Na}_{2} \mathrm{SO}_{4}$ and concentrated to dryness. The crude material was purified by flash chromatography $\left(\mathrm{CH}_{2} \mathrm{Cl}_{2}\right.$ as eluent) to furnish the desired product as a brown solid $(16.1 \mathrm{mg}, 67 \%)$. The UV-vis spectrum of Mn(N)-SalophOMe is shown in Figure S1. Crystals suitable for X-ray analysis were grown from $\mathrm{CH}_{2} \mathrm{Cl}_{2} / \mathrm{Et}_{2} \mathrm{O}$ mixture.

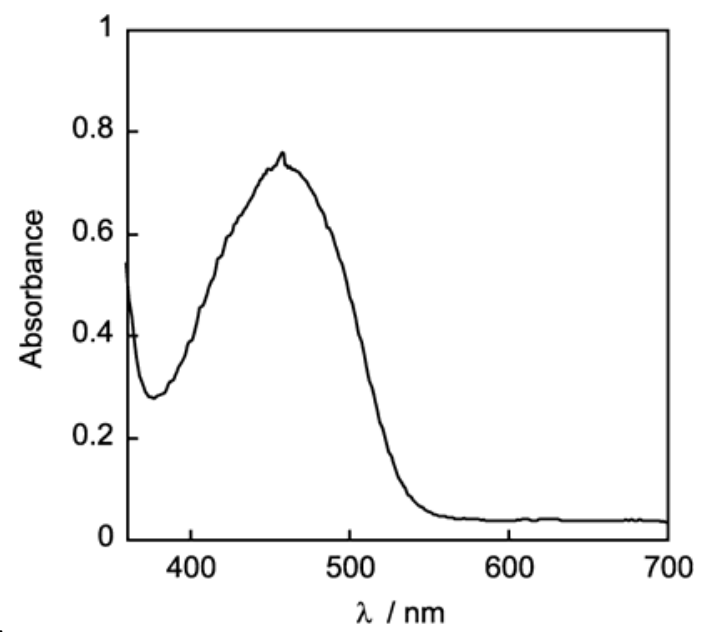

Figure S1. The UV-vis spectrum of a solution of $5.0 \times 10^{-5} \mathrm{M} \mathbf{M n}(\mathbf{N})$-Saloph-OMe in 1:1 MeOH:MeCN at room temperature. 


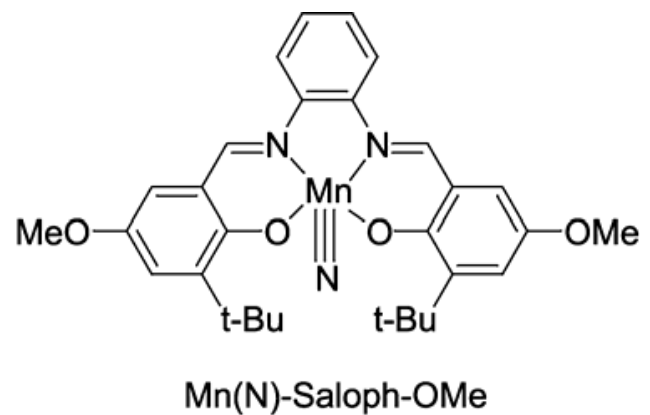

${ }^{1} \mathrm{H}$ NMR (500 MHz, $\mathrm{CD}_{2} \mathrm{Cl}_{2}$ ): $\delta 8.84(\mathrm{~s}, 2 \mathrm{H}), 7.85(\mathrm{dd}, J=6.0 \mathrm{~Hz}, 3.0 \mathrm{~Hz}, 2 \mathrm{H}), 7.40(\mathrm{dd}, J=6.0$ $\mathrm{Hz}, 3.0 \mathrm{~Hz}, 2 \mathrm{H}), 7.21$ (d, $J=3.5 \mathrm{~Hz}, 2 \mathrm{H}), 6.71(\mathrm{~d}, J=3.5 \mathrm{~Hz}, 2 \mathrm{H}), 3.81(\mathrm{~s}, 6 \mathrm{H}), 1.48(\mathrm{~s}, 18 \mathrm{H})$. ${ }^{13} \mathrm{C}$ NMR $\left(125 \mathrm{MHz}, \mathrm{CD}_{2} \mathrm{Cl}_{2}\right): \delta 166.6,158.4,150.4,145.7,143.9,128.0,126.4,119.3,115.6$, 110.6, 56.1, 36.3, 29.9. FTIR (thin film) 2944, 1602, 1582, 1534, 1458, 1427, 1411, 1387, 1359, 1312, 1212, 1191, 1059, 1040. HRMS (ESI) Calcd for $\mathrm{C}_{30} \mathrm{H}_{34} \mathrm{MnN}_{3} \mathrm{O}_{4}: \mathrm{M}^{+}=555.1930$. Found 555.1911 .

X-Ray Structure of Mn(N)-SalophOMe. X-ray diffraction experiments were performed on single crystals grown from concentrated solutions of $\mathbf{M n}(\mathbf{N})$-SalophOMe in methylene chloride/ether mixture at room temperature. Crystals were removed from the supernatant liquid and transferred onto a microscope slide coated with Paratone N oil. Selected crystals were affixed to a glass fiber and cooled to $-173{ }^{\circ} \mathrm{C}$. Data collection was performed by shining MoK $\alpha$ $(\lambda=0.71073 \AA)$ radiation onto crystals mounted onto a Bruker CCD diffractometer. The data were processed and refined by using the program SAINT supplied by Siemens Industrial Automation, Inc. The structures were solved by direct methods (SHELXTL v6.10, Sheldrick, G. M., and Siemens Industrial Automation, Inc., 2000) in conjunction with standard difference Fourier techniques. All non-hydrogen atoms were refined anisotropically unless otherwise noted. Hydrogen atoms were placed in calculated positions. A disordered molecule of methylene chloride crystallized with the complex. The molecule was modeled over two positions with occupancies of 0.506 and 0.494 . The crystal structure of the nitride complex is shown in Figure S2.

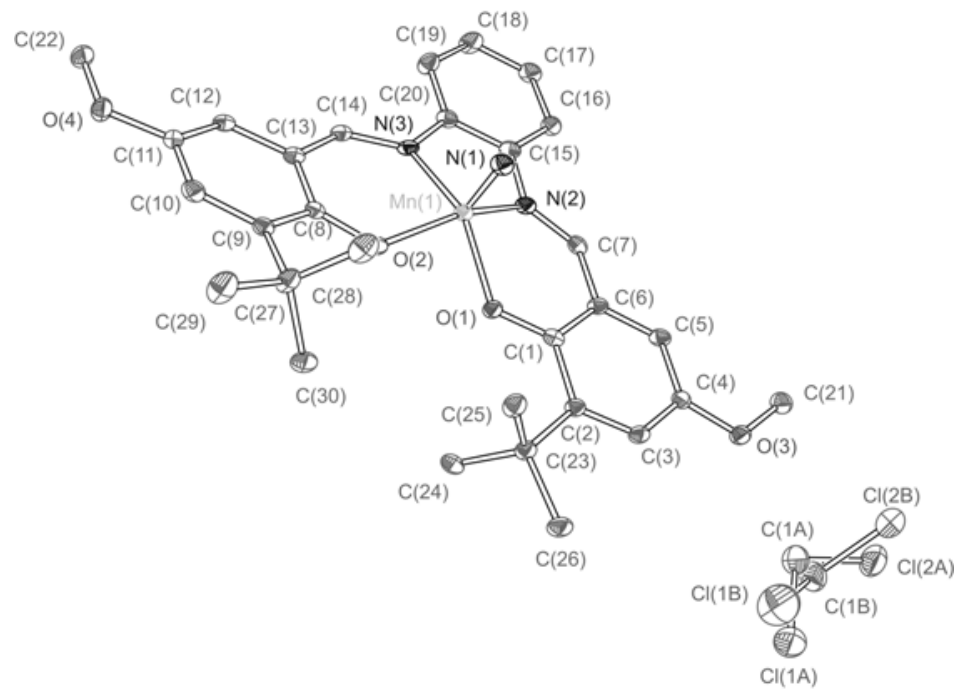

Figure S2. The crystal structure of $\mathbf{M n}(\mathbf{N})-$ SalophOMe. Thermal ellipsoids are drawn at the $50 \%$ probability level. Atom labeling scheme used in Tables S1 - S6. 


\section{Synthesis of EHSX-Mn-SalophOMe (2)}

The synthesis was accomplished through the sequence described in Scheme S1. A vial containing a stirbar was charged with $\mathbf{S 1}^{2}(21.0 \mathrm{mg}, 0.0373 \mathrm{mmol})$ and 3-tert-butyl-2-hydroxy-5methoxy-benzaldehyde ${ }^{1}(16.0 \mathrm{mg}, 0.078 \mathrm{mmol})$. Ethanol $(0.5 \mathrm{~mL})$ was added, the vial was sealed with a Teflon cap, and the reaction mixture was allowed to stir at $100{ }^{\circ} \mathrm{C}$ for $24 \mathrm{~h}$. The desired product precipitated out of solution as a red-orange solid and was collected on a glass frit after filtering and copious washings with $\mathrm{EtOH}(26 \mathrm{mg}, 74 \%)$. The resulting material was purified by column chromatography (pentane $/ \mathrm{CH}_{2} \mathrm{Cl}_{2}=1: 1$ ) to afford the desired ligand EHSX$\mathbf{H}_{2}$-SalophOMe as a yellow solid ( $24 \mathrm{mg}, 69 \%$ ).

\section{Scheme S1}

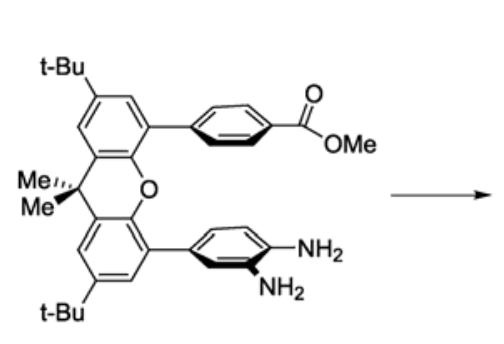

S1

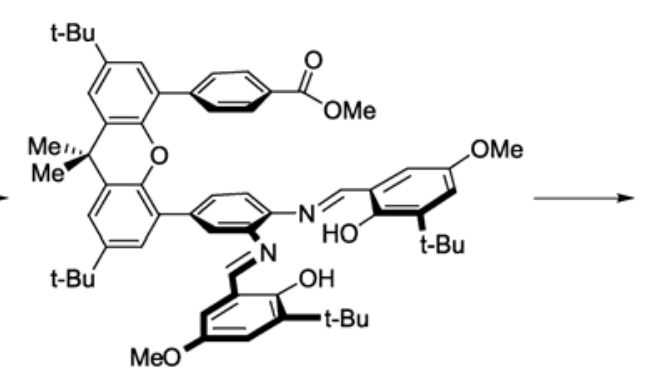

EHSX $+\mathrm{H}_{2}$-SalophOMe

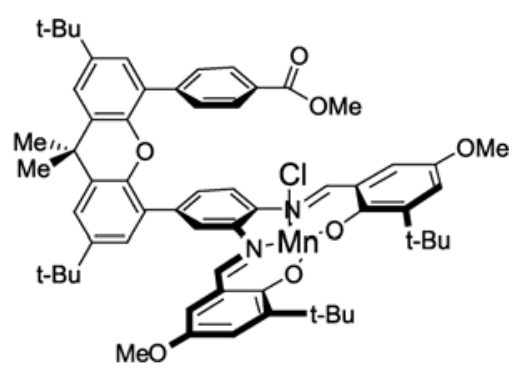

EHSX-Mn-SalophOMe

${ }^{1} \mathrm{H}$ NMR (500 MHz, $\left.\mathrm{CD}_{2} \mathrm{Cl}_{2}\right): \delta 13.50(\mathrm{~s}, 1 \mathrm{H}), 13.41(\mathrm{~s}, 1 \mathrm{H}), 8.75(\mathrm{~s}, 1 \mathrm{H}), 7.97(\mathrm{~s}, 1 \mathrm{H}), 7.67(\mathrm{~d}, J$ $=8.0 \mathrm{~Hz}, 2 \mathrm{H}), 7.53(\mathrm{~d}, J=2.5 \mathrm{~Hz}, 1 \mathrm{H}), 7.52(\mathrm{~d}, J=2.5 \mathrm{~Hz}, 1 \mathrm{H}), 7.38(\mathrm{~d}, J=8.0 \mathrm{~Hz}, 2 \mathrm{H}), 7.32$ $(\mathrm{dd}, \mathrm{J}=8.5 \mathrm{~Hz}, \mathrm{~J}=2.0 \mathrm{~Hz}, 1 \mathrm{H}), 7.31(\mathrm{~d}, J=2.5 \mathrm{~Hz}, 1 \mathrm{H}), 7.25(\mathrm{~d}, J=2.5 \mathrm{~Hz}, 1 \mathrm{H}), 7.22(\mathrm{~d}, J=$ $2.0 \mathrm{~Hz}, 1 \mathrm{H}), 7.18(\mathrm{~d}, J=8.0 \mathrm{~Hz}, 1 \mathrm{H}), 7.06(\mathrm{~d}, J=3.0 \mathrm{~Hz}, 1 \mathrm{H}), 7.02(\mathrm{~d}, J=3.0 \mathrm{~Hz}, 1 \mathrm{H}), 6.97(\mathrm{~d}$, $J=3.0 \mathrm{~Hz}, 1 \mathrm{H}), 6.58(\mathrm{~d}, J=3.0 \mathrm{~Hz}, 1 \mathrm{H}), 3.85(\mathrm{~s}, 3 \mathrm{H}), 3.78(\mathrm{~s}, 3 \mathrm{H}), 3.51(\mathrm{~s}, 3 \mathrm{H}), 1.76(\mathrm{~s}, 6 \mathrm{H})$, $1.46(\mathrm{~s}, 9 \mathrm{H}), 1.43(\mathrm{~s}, 9 \mathrm{H}), 1.39(\mathrm{~s}, 9 \mathrm{H}), 1.37(\mathrm{~s}, 9 \mathrm{H}) .{ }^{13} \mathrm{C} \mathrm{NMR}\left(125 \mathrm{MHz}, \mathrm{CD}_{2} \mathrm{Cl}_{2}\right): \delta 167.0$, 164.8, 164.3, 155.9, 155.8, 152.1, 151.9, 146.5, 146.4, 146.3, 146.1, 143.4, 142.1, 142.0, 139.72, $139.70,138.3,131.2,130.9,130.1,129.4,129.3,129.0,128.9,128.5,126.4,126.3,123.1,122.7$, 121.6, 120.1, 120.0, 119.8, 119.3, 118.8, 112.7, 112.5, 56.24, 56.20, 52.3, 35.7, 35.51, 35.49, 35.08, 35.05, 32.1, 31.85, 31.80, 29.61, 29.60. FTIR (thin film) 2958, 2870, 1719, 1611, 1577, $1445,1393,1362,1333,1279,1234,1211,1151,1061$. HRMS (ESI) Calcd for $\mathrm{C}_{61} \mathrm{H}_{70} \mathrm{~N}_{2} \mathrm{O}_{7}: \mathrm{M}$ $+\mathrm{H}^{+}=943.5256$. Found 943.5237 .

A vial containing a stirbar was charged with EHSX-H $\mathbf{H}_{2}$-SalophOMe $(21.0 \mathrm{mg}, 0.0222 \mathrm{mmol})$ and $\mathrm{Mn}(\mathrm{OAc})_{2} \bullet 4 \mathrm{H}_{2} \mathrm{O}(6.0 \mathrm{mg}, 0.025 \mathrm{mmol})$. Ethanol $(1.0 \mathrm{~mL})$ was added, followed by $\mathrm{CH}_{2} \mathrm{Cl}_{2}$ $(0.2 \mathrm{~mL})$ and the reaction mixture was stirred at room temperature for $24 \mathrm{~h}$. The dark brown reaction mixture was diluted with $\mathrm{CH}_{2} \mathrm{Cl}_{2}$. The organic extract was washed with brine, dried over $\mathrm{Na}_{2} \mathrm{SO}_{4}$, and concentrated under vacuum. The crude material was purified by column chromatography $\left(\mathrm{CH}_{2} \mathrm{Cl}_{2} / \mathrm{Et}_{2} \mathrm{O}\right.$ gradient), and the desired EHSX-Mn-SalophOMe was obtained 
as a brown solid (22 mg, 96\%). HRMS (ESI) Calcd for $\mathrm{C}_{61} \mathrm{H}_{68} \mathrm{~N}_{2} \mathrm{O}_{7} \mathrm{MnCl}$ : $[\mathrm{M}-\mathrm{Cl}]^{+}=995.4402$. Found 995.4436.

\section{Stopped-Flow UV-VIS Kinetic Measurements}

General considerations. All solutions were prepared and handled in an inert atmosphere, argonfilled glove box, unless otherwise noted. Kinetics measurements were made using a Hi-Tech Scientific (Salisbury, Wiltshire, U.K.) SF-43 multi-mixing anaerobic cryogenic stopped-flow instrument equipped with a Hi-Tech Scientific Kinetascan diode array rapid scanning unit. Fullspectral kinetics data were fitted globally with the commercially available software Specfit32 from Spectrum Software Associates (Marlborough, Massachusetts) or at single wavelengths or with IS-2 Rapid Scanning Kinetic Software (Hi-Tech Scientific).

Materials. $\mathrm{MeOH}$ (anhydrous) was used as received (Burdick \& Jackson). All other solvents were purchased from VWR Scientific Products, passed through an M. Braun, Inc. purification system and sparged with $\mathrm{N}_{2}$ to remove trace $\mathrm{O}_{2}$ prior to use. 3-Chloroperoxybenzoic acid ( $\mathrm{m}$ CPBA) was purchased from Aldrich (77\%) and purified by washing with $\mathrm{pH} 7.40$ phosphate buffer and recrystallization from pentane to remove 3-chlorobenzoic acid. Purity ( $>95 \%)$ was determined by $1 \mathrm{H}$ NMR.

Stopped-Flow Kinetics. In a representative procedure, a gas-tight syringe was charged with 8.0 $\times 10^{-5}$ M HSX-Mn-SalophOMe (1) in 1:1 MeOH:MeCN (25 mL, $\left.2.0 \mu \mathrm{mol}\right)$. A second gas-tight syringe was charged with $6.6 \times 10^{-4} \mathrm{M}$ m-CPBA in 1:1 MeOH:MeCN (25 mL, $\left.17 \mu \mathrm{mol}\right)$. The solutions were loaded into the stopped-flow spectrophotometer and triggered by simultaneous injection of $0.1 \mathrm{~mL}$ of each solution to make the reactant concentrations $4.0 \times 10^{-5} \mathrm{M}$ and $3.3 \times$ $10^{-4} \mathrm{M}$ in manganese and $m$-CPBA, respectively. The solutions were cooled to $-20{ }^{\circ} \mathrm{C}$ prior to mixing and maintained at that temperature in a chilled heptane bath throughout the reaction. The reaction was monitored by UV-vis spectroscopy. Spectra $(350-700 \mathrm{~nm})$ were acquired for $100 \mathrm{~s}$ at 0.5 second intervals. Figure S3a shows the absorption spectrum of the Mn(III) substitution of the axial chloride ligand of the reactant by the $m$-CPBA substrate. The spectral changes associated with the addition of the non-reactive benzoate, which serves as a model for the substitution reaction, are shown in Figure S3b. 

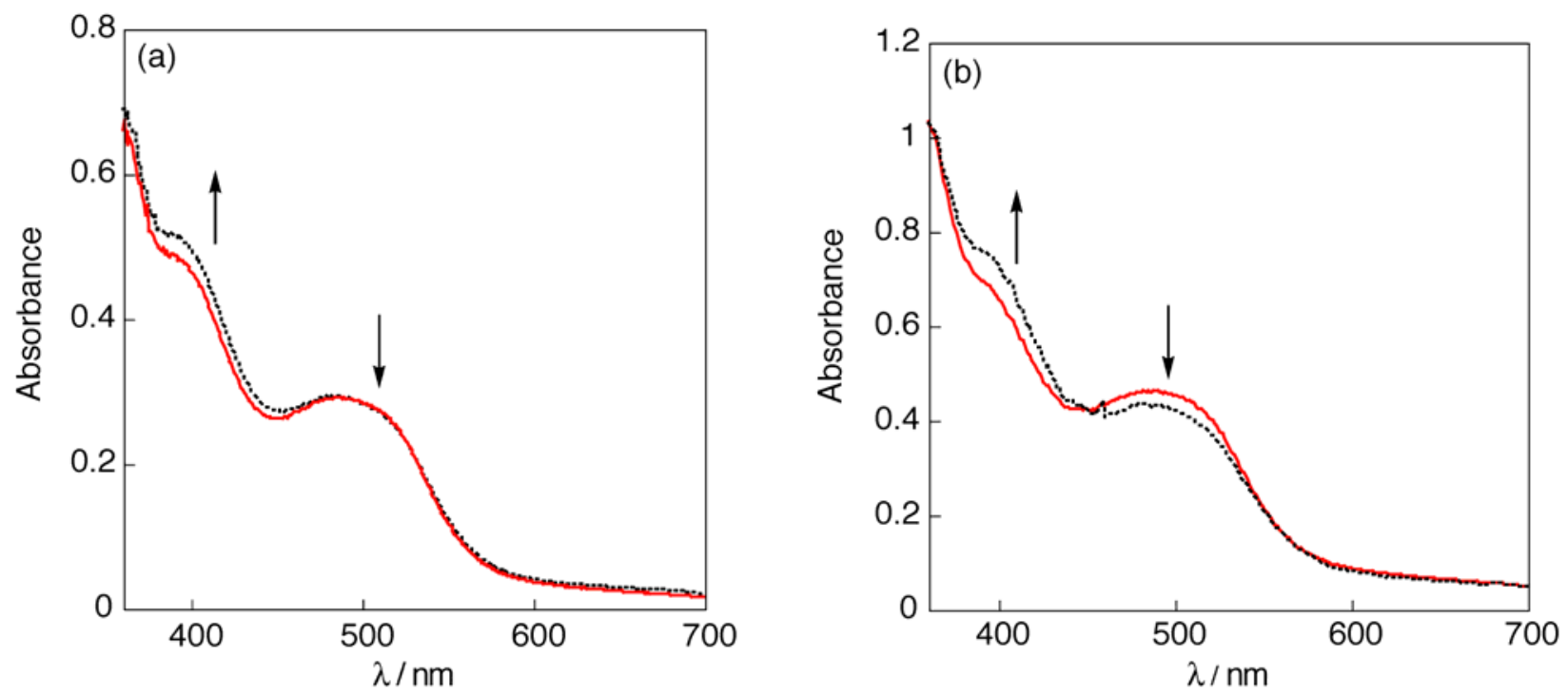

Figure S3. (a) Stopped-flow UV-vis spectra obtained from reactions of $m$-CPBA $\left(3.3 \times 10^{-4} \mathrm{M}\right)$ with 4.0 $\times 10^{-5} \mathrm{M} 1$ (red solid line) ca. $3 \mathrm{~s}$ post injection in 1:1 $\mathrm{MeOH}: \mathrm{MeCN}$ at $-20{ }^{\circ} \mathrm{C}$. (b) $\mathrm{UV}$-vis spectrum obtained from a solution of $5.0 \times 10^{-5} \mathrm{M} 1$ in 1:1 MeOH:MeCN at room temperature (red solid line). UVvis spectrum obtained from a solution of $5.0 \times 10^{-5} \mathrm{M} 1$ in 1:1 $\mathrm{MeOH}: \mathrm{MeCN}$ at room temperature in the presence of benzoic acid $\left(5.0 \times 10^{-3} \mathrm{M}\right)$ (black dotted line).

\section{Experimental Protocol for Hydrogen Peroxide Disproportionation Reactions}

Dismutation reactions were performed at room temperature in a sealed (PTFE septum) $3 \mathrm{~mL}$ reaction vial equipped with a magnetic stirbar and a capillary gas delivery tube linked to a graduated burette filled with water. The reaction vial was charged with a stock solution of the corresponding catalyst in $\mathrm{CH}_{2} \mathrm{Cl}_{2}(1.0 \mathrm{~mL})$. $\mathrm{MeOH}(0.5 \mathrm{~mL})$ was added followed by $\mathrm{H}_{2} \mathrm{O}_{2}(790$ $\mu \mathrm{L}, 8.22 \mathrm{mmol} ; 10.4 \mathrm{M}(30 \%)$ aq. solution), and the reaction mixture was stirred vigorously. The time was set to zero immediately after addition of $\mathrm{H}_{2} \mathrm{O}_{2}$. The conversion of the reaction was monitored volumetrically, and the amount of produced $\mathrm{O}_{2}(\mathrm{n})$ was calculated through the perfect gas equation $\mathrm{pV}=\mathrm{nRT}$, assuming that $\mathrm{p}=1 \mathrm{~atm}$.

The amounts of catalyst used to obtain the results of Table 2: HSX-Mn-SalophOMe (1.0 mg, $0.00098 \mathrm{mmol}$; from a $1.0 \mathrm{mg} / \mathrm{mL} \mathrm{CH}_{2} \mathrm{Cl}_{2}$ stock solution) to give $106 \mathrm{~cm}^{3}$ of $\mathrm{O}_{2}$ in $1 \mathrm{~h}$; EHSXMn-SalophOMe (1.0 mg, $0.00097 \mathrm{mmol}$; from a $1.0 \mathrm{mg} / \mathrm{mL} \mathrm{CH}_{2} \mathrm{Cl}_{2}$ stock solution) to give 13.0 $\mathrm{cm}^{3}$ of $\mathrm{O}_{2}$ in $1 \mathrm{~h}$; and Mn-SalophOMe $(0.56 \mathrm{mg}, 0.00098 \mathrm{mmol})$ and benzoic acid $(0.12 \mathrm{mg}$, $0.00098 \mathrm{mmol}$; from a stock solution of Mn-SalophOMe $(5.6 \mathrm{mg}, 0.0098 \mathrm{mmol})$ and benzoic acid $(1.2 \mathrm{mg}, 0.0098 \mathrm{mmol})$ in $\left.10.0 \mathrm{~mL} \mathrm{CH}_{2} \mathrm{Cl}_{2}\right)$ to give $2.5 \mathrm{~cm}^{3}$ of $\mathrm{O}_{2}$ in $1 \mathrm{~h}$.

\section{UV-VIS Kinetics of HSX-Mn-SalophOMe (1) Decomposition in the Presence of $\mathrm{H}_{2} \mathrm{O}_{2}$}

General procedure for measuring the kinetics of the decomposition of 1 in the presence of $\mathbf{H}_{2} \mathbf{O}_{2}$. Kinetic studies were performed in a sealed quartz cuvette at room temperature. The cuvette was charged with a stock solution of $1\left(2.6 \times 10^{-5} \mathrm{M}\right)$ in $\mathrm{MeOH}(3.0 \mathrm{~mL}) \cdot \mathrm{H}_{2} \mathrm{O}_{2}$ was 
added $(50 \mu \mathrm{L} ; 32 \%$ aq. solution; $\mathrm{d}=1.1126 \mathrm{~g} / \mathrm{mL})$, thereby generating a $2.5 \times 10^{-5} \mathrm{M}, 0.17 \mathrm{M}$, and $0.69 \mathrm{M}$ solution of $1, \mathrm{H}_{2} \mathrm{O}_{2}$, and $\mathrm{H}_{2} \mathrm{O}$, respectively. The time was set to zero immediately after addition of $\mathrm{H}_{2} \mathrm{O}_{2}$. The first spectrum was taken 30 seconds after injection of $\mathrm{H}_{2} \mathrm{O}_{2}$. The progress of the reaction was monitored by UV-vis spectroscopy at two minute intervals. The corresponding spectra (up to $19 \%$ conversion) are illustrated in Figure S4. The decrease in absorbance at $500 \mathrm{~nm}$ was fitted to an exponential function, and $\mathrm{k}_{\mathrm{obs}}$ was determined to be $2.9 \times$ $10^{-4} \mathrm{~s}^{-1}$.

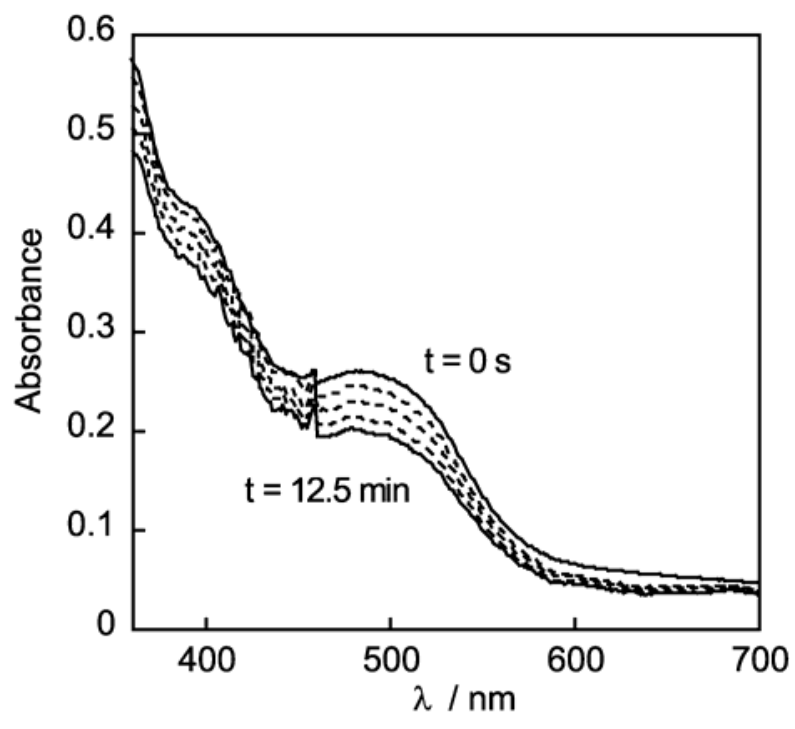

Figure S4. UV-vis spectra of a solution of $\mathbf{1}\left(2.5 \times 10^{-5} \mathrm{M}\right)$ in $\mathrm{MeOH}$ in the presence of $0.17 \mathrm{M} \mathrm{H}_{2} \mathrm{O}_{2}$ recorded over a period of 13 minutes at room temperature.

Rate dependence on $\mathrm{H}_{2} \mathrm{O}$ concentration-reaction order with respect to $\mathrm{H}_{2} \mathrm{O}$. The general procedure was used, employing $3.0 \mathrm{~mL}$ of a solution of $\mathbf{1}\left(2.6 \times 10^{-5} \mathrm{M}\right)$ in $\mathrm{MeOH}$ and $50 \mu \mathrm{L}$ of $\mathrm{H}_{2} \mathrm{O}_{2}$ (32\% aq.). Different amounts of $\mathrm{H}_{2} \mathrm{O}$ were added to measure the rate dependence of $\mathrm{H}_{2} \mathrm{O}$ concentration:

(1) $0 \mu \mathrm{L}$ additional $\mathrm{H}_{2} \mathrm{O}$, furnishing $\mathrm{k}_{\mathrm{obs}}=2.9 \times 10^{-4} \mathrm{~s}^{-1}$ see above for details.

(2) $38 \mu \mathrm{L}$ additional $\mathrm{H}_{2} \mathrm{O}$, thereby generating a $2.5 \times 10^{-5} \mathrm{M}, 0.17 \mathrm{M}$, and $1.4 \mathrm{M}$ solution of $\mathbf{1}$, $\mathrm{H}_{2} \mathrm{O}_{2}$, and $\mathrm{H}_{2} \mathrm{O}$, respectively. Thus, $\mathrm{k}_{\mathrm{obs}}$ was determined to be $2.4 \times 10^{-4} \mathrm{~s}^{-1}$.

(3) $190 \mu \mathrm{L}$ additional $\mathrm{H}_{2} \mathrm{O}$, thereby generating a $2.4 \times 10^{-5} \mathrm{M}, 0.16 \mathrm{M}$, and $3.9 \mathrm{M}$ solution of $\mathbf{1}$, $\mathrm{H}_{2} \mathrm{O}_{2}$, and $\mathrm{H}_{2} \mathrm{O}$, respectively. Thus, $\mathrm{k}_{\mathrm{obs}}$ was determined to be $1.9 \times 10^{-4} \mathrm{~s}^{-1}$.

Log $\mathrm{k}_{\mathrm{obs}}$ was plotted against $\log \left[\mathrm{H}_{2} \mathrm{O}\right]$, and the data were fitted to a linear function. The corresponding slope gave a value of -0.2 . Thus, the reaction displays a near zero-order dependence on $\left[\mathrm{H}_{2} \mathrm{O}\right]$.

Rate dependence on $\mathrm{H}_{2} \mathrm{O}_{2}$ concentration-reaction order with respect to $\mathrm{H}_{2} \mathrm{O}_{2}$. The general procedure was used, employing $3.0 \mathrm{~mL}$ of a solution of $1\left(2.610^{-5} \mathrm{M}\right)$ in $\mathrm{MeOH}$. Different amounts of $\mathrm{H}_{2} \mathrm{O}_{2}\left(32 \%\right.$ aq.) and $\mathrm{H}_{2} \mathrm{O}$ were added to measure the rate dependence of $\mathrm{H}_{2} \mathrm{O}_{2}$ 
concentration:

(1) $25 \mu \mathrm{L} \mathrm{H}_{2} \mathrm{O}_{2}$ and $208 \mu \mathrm{L} \mathrm{H} \mathrm{H}_{2} \mathrm{O}$, thereby generating a $2.4 \times 10^{-5} \mathrm{M}, 0.080 \mathrm{M}$, and $3.9 \mathrm{M}$ solution of $1, \mathrm{H}_{2} \mathrm{O}_{2}$, and $\mathrm{H}_{2} \mathrm{O}$, respectively. Thus, $\mathrm{k}_{\mathrm{obs}}$ was determined to be $1.3 \times 10^{-4} \mathrm{~s}^{-1}$.

(2) $50 \mu \mathrm{L} \mathrm{H}_{2} \mathrm{O}_{2}$ and $190 \mu \mathrm{L} \mathrm{H} \mathrm{H}_{2} \mathrm{O}$, thereby generating a $2.4 \times 10^{-5} \mathrm{M}, 0.16 \mathrm{M}$, and $3.9 \mathrm{M}$ solution of $1, \mathrm{H}_{2} \mathrm{O}_{2}$, and $\mathrm{H}_{2} \mathrm{O}$, respectively. Thus, $\mathrm{k}_{\text {obs }}$ was determined to be $1.9 \times 10^{-4} \mathrm{~s}^{-1}$

(3) $100 \mu \mathrm{L} \mathrm{H}_{2} \mathrm{O}_{2}$ and $151 \mu \mathrm{L} \mathrm{H} \mathrm{H}_{2} \mathrm{O}$, thereby generating a $2.4 \times 10^{-5} \mathrm{M}, 0.32 \mathrm{M}$, and $3.9 \mathrm{M}$ solution of $1, \mathrm{H}_{2} \mathrm{O}_{2}$, and $\mathrm{H}_{2} \mathrm{O}$, respectively. Thus, $\mathrm{k}_{\mathrm{obs}}$ was determined to be $3.9 \times 10^{-4} \mathrm{~s}^{-1}$.

Log $\mathrm{k}_{\mathrm{obs}}$ was plotted against $\log \left[\mathrm{H}_{2} \mathrm{O}_{2}\right]$, and the data were fitted to a linear function. The corresponding slope gave a value of 0.8 . Thus, the reaction displays a near first-order dependence on $\left[\mathrm{H}_{2} \mathrm{O}_{2}\right]$.

Rate dependence on the concentration of 1 -reaction order with respect to 1 . The general procedure was used, employing $50 \mu \mathrm{L} \mathrm{H}_{2} \mathrm{O}_{2}$ (32\% aq.) and $3.0 \mathrm{~mL}$ of a solution of 1 in $\mathrm{MeOH}$ at different concentrations:

(1) At the following concentrations: $[1]=8.4 \times 10^{-6} \mathrm{M},\left[\mathrm{H}_{2} \mathrm{O}\right]=0.69 \mathrm{M},\left[\mathrm{H}_{2} \mathrm{O}_{2}\right]=0.17 \mathrm{M}, \mathrm{k}_{\text {obs }}$ was determined to be $2.910^{-4} \mathrm{~s}^{-1}$.

(2) At the following concentrations: $[1]=2.5 \times 10^{-5} \mathrm{M},\left[\mathrm{H}_{2} \mathrm{O}\right]=0.69 \mathrm{M},\left[\mathrm{H}_{2} \mathrm{O}_{2}\right]=0.17 \mathrm{M}, \mathrm{k}_{\mathrm{obs}}$ was determined to be $2.910^{-4} \mathrm{~s}^{-1}$.

(3) At the following concentrations: $[1]=5.2 \times 10^{-6} \mathrm{M},\left[\mathrm{H}_{2} \mathrm{O}\right]=0.69 \mathrm{M},\left[\mathrm{H}_{2} \mathrm{O}_{2}\right]=0.17 \mathrm{M}, \mathrm{k}_{\text {obs }}$ was determined to be $2.7 \times 10^{-4} \mathrm{~s}^{-1}$.

$\log \mathrm{k}_{\mathrm{obs}}$ was plotted against $\log [\mathbf{1}]$, and the data were fitted to a linear function. The corresponding slope gave a value of 0.0 . Because of the relationship between $\mathrm{k}_{\mathrm{obs}}$ and the reaction order as described by equations (S1), the decomposition reaction is first order with respect to $[\mathbf{1}](=[\mathrm{cat}])$.

$$
\begin{aligned}
& {[c a t]_{(t)}=[c a t]_{0} e^{-k_{o b s} t}} \\
& \left(\frac{d[c a t]}{d t}\right)_{0}=-k_{o b s}[c a t]_{0}=-k_{d}[c a t]_{0}^{a} \\
& \log \left[k_{o b s}\right]=\log \left(k_{d}\right)+(a-1) \log [c a t]_{0} \\
& \text { slope }=a-1
\end{aligned}
$$


Table S1. Crystal data and structure refinement for Mn(N)-SalophOMe

\begin{tabular}{|c|c|c|}
\hline Identification code & c05027 & \\
\hline Empirical formula & $\mathrm{C} 31 \mathrm{H} 36 \mathrm{Cl} 2 \mathrm{MnN} 3 \mathrm{O} 4$ & \\
\hline Formula weight & 640.47 & \\
\hline Temperature & $100(2) \mathrm{K}$ & \\
\hline Wavelength & $0.71073 \AA$ & \\
\hline Crystal system & Triclinic & \\
\hline Space group & $\mathrm{P}^{-} 1$ & \\
\hline \multirow[t]{3}{*}{ Unit cell dimensions } & $a=7.2200(9) \AA$ & $\alpha=114.143(2)^{\circ}$ \\
\hline & $\mathrm{b}=14.4556(17) \AA$ & $\beta=98.391(2)^{\circ}$ \\
\hline & $\mathrm{c}=16.314(2) \AA$ & $\gamma=94.889(3)^{\circ}$ \\
\hline Volume & $1517.2(3) \AA 3$ & \\
\hline $\mathrm{Z}$ & 2 & \\
\hline Density (calculated) & $1.402 \mathrm{Mg} / \mathrm{m} 3$ & \\
\hline Absorption coefficient & $0.652 \mathrm{~mm}-1$ & \\
\hline $\mathrm{F}(000)$ & 668 & \\
\hline Crystal size & $0.21 \times 0.09 \times 0.07 \mathrm{~mm} 3$ & \\
\hline Theta range for data collection & 1.56 to $23.26^{\circ}$. & \\
\hline \multirow[t]{3}{*}{ Index ranges } & $-8 \leq \mathrm{h} \leq 5$ & \\
\hline & $-16 \leq \mathrm{k} \leq 14$ & \\
\hline & $-18 \leq 1 \leq 18$ & \\
\hline Reflections collected & 7234 & \\
\hline Independent reflections & $4316\left[\mathrm{R}_{\mathrm{int}}=0.0285\right]$ & \\
\hline Completeness to theta $=23.26^{\circ}$ & $99.1 \%$ & \\
\hline Absorption correction & Empirical SADABS & \\
\hline Refinement method & Full-matrix least-squares on $\mathrm{F} 2$ & \\
\hline Data / restraints / parameters & $4316 / 3 / 406$ & \\
\hline Goodness-of-fit on F2 & 1.067 & \\
\hline Final R indices $[\mathrm{I}>2 \sigma \mathrm{I}]$ & $\mathrm{R} 1=0.0492, \mathrm{wR} 2=0.1255$ & \\
\hline $\mathrm{R}$ indices (all data) & $\mathrm{R} 1=0.0590, \mathrm{wR} 2=0.1308$ & \\
\hline Largest diff. peak and hole & $0.529 \mathrm{e}^{-3}$ & $-0.598 \mathrm{e}^{-3}$ \\
\hline
\end{tabular}


Table S2. Atomic coordinates $\left(\times 10^{4}\right)$ and equivalent isotropic displacement parameters $\left(\AA^{2} \times\right.$ $10^{3}$ ) for $\mathbf{M n}(\mathbf{N})$-SalophOMe. $\mathrm{U}(\mathrm{eq})$ is defined as one third of the trace of the orthogonalized $U_{i j}$ tensor.

\begin{tabular}{|c|c|c|c|c|}
\hline Atom & $\mathrm{x}$ & $\mathrm{y}$ & $\mathrm{z}$ & $\mathrm{U}(\mathrm{eq})$ \\
\hline $\operatorname{Mn}(1)$ & $-40(1)$ & $2793(1)$ & $3281(1)$ & $16(1)$ \\
\hline $\mathrm{N}(1)$ & $-1850(4)$ & $2801(2)$ & $3658(2)$ & $21(1)$ \\
\hline $\mathrm{N}(2)$ & $942(4)$ & $4271(2)$ & $3788(2)$ & $17(1)$ \\
\hline $\mathrm{N}(3)$ & $-760(4)$ & 2992(2) & 2161(2) & $17(1)$ \\
\hline $\mathrm{O}(1)$ & 1972(3) & $2646(2)$ & 4092(2) & $19(1)$ \\
\hline $\mathrm{O}(2)$ & $31(3)$ & $1369(2)$ & $2563(2)$ & $18(1)$ \\
\hline $\mathrm{O}(3)$ & 5895(4) & $5423(2)$ & $7535(2)$ & $24(1)$ \\
\hline $\mathrm{O}(4)$ & $-3548(4)$ & $-1251(2)$ & $-987(2)$ & $26(1)$ \\
\hline$C(1)$ & $2880(5)$ & $3336(3)$ & 4903(2) & $18(1)$ \\
\hline$C(2)$ & $3965(5)$ & $3006(3)$ & $5531(2)$ & $17(1)$ \\
\hline$C(3)$ & $4880(5)$ & $3746(3)$ & 6379(2) & $19(1)$ \\
\hline $\mathrm{C}(4)$ & $4878(5)$ & $4808(3)$ & 6663(2) & $18(1)$ \\
\hline$C(5)$ & $3944(5)$ & $5146(3)$ & $6070(2)$ & 19(1) \\
\hline$C(6)$ & $2920(5)$ & 4414(3) & $5193(2)$ & $17(1)$ \\
\hline$C(7)$ & $2069(5)$ & 4814(3) & $4584(2)$ & $18(1)$ \\
\hline$C(8)$ & $-909(5)$ & $777(3)$ & $1727(2)$ & $17(1)$ \\
\hline $\mathrm{C}(9)$ & $-1394(5)$ & $-311(3)$ & $1437(2)$ & $18(1)$ \\
\hline $\mathrm{C}(10)$ & $-2239(5)$ & $-914(3)$ & $534(2)$ & $22(1)$ \\
\hline $\mathrm{C}(11)$ & $-2689(5)$ & $-519(3)$ & $-124(2)$ & $20(1)$ \\
\hline $\mathrm{C}(12)$ & $-2316(5)$ & $517(3)$ & $143(2)$ & $18(1)$ \\
\hline $\mathrm{C}(13)$ & $-1468(5)$ & 1184(3) & 1072(2) & $18(1)$ \\
\hline $\mathrm{C}(14)$ & $-1238(5)$ & $2257(3)$ & $1322(2)$ & $18(1)$ \\
\hline$C(15)$ & $211(5)$ & $4742(3)$ & $3220(2)$ & $18(1)$ \\
\hline$C(16)$ & $321(5)$ & $5807(3)$ & $3495(3)$ & $20(1)$ \\
\hline $\mathrm{C}(17)$ & $-506(5)$ & $6152(3)$ & 2869(3) & $24(1)$ \\
\hline $\mathrm{C}(18)$ & $-1423(6)$ & $5467(3)$ & 1996(3) & $27(1)$ \\
\hline $\mathrm{C}(19)$ & $-1547(6)$ & $4418(3)$ & $1718(3)$ & $25(1)$ \\
\hline $\mathrm{C}(20)$ & $-712(5)$ & $4045(3)$ & 2331(2) & $19(1)$ \\
\hline $\mathrm{C}(21)$ & $5946(6)$ & $6507(3)$ & $7855(3)$ & $25(1)$ \\
\hline $\mathrm{C}(22)$ & $-4117(6)$ & $-885(3)$ & $-1666(2)$ & 24(1) \\
\hline
\end{tabular}




\begin{tabular}{lllll}
$\mathrm{C}(23)$ & $4053(5)$ & $1855(3)$ & $5244(2)$ & $20(1)$ \\
$\mathrm{C}(24)$ & $4955(6)$ & $1434(3)$ & $4391(3)$ & $23(1)$ \\
$\mathrm{C}(25)$ & $2021(5)$ & $1256(3)$ & $5049(3)$ & $23(1)$ \\
$\mathrm{C}(26)$ & $5282(6)$ & $1683(3)$ & $6010(3)$ & $26(1)$ \\
$\mathrm{C}(27)$ & $-1101(6)$ & $-766(3)$ & $2145(2)$ & $23(1)$ \\
$\mathrm{C}(28)$ & $-2173(6)$ & $-233(3)$ & $2912(3)$ & $30(1)$ \\
$\mathrm{C}(29)$ & $-1876(7)$ & $-1924(3)$ & $1706(3)$ & $37(1)$ \\
$\mathrm{C}(30)$ & $1038(6)$ & $-623(3)$ & $2558(3)$ & $28(1)$ \\
$\mathrm{C}(1 \mathrm{~A})$ & $7000(20)$ & $4459(8)$ & $8808(8)$ & $36(3)$ \\
$\mathrm{Cl}(1 \mathrm{~A})$ & $7698(7)$ & $3480(3)$ & $9111(3)$ & $47(1)$ \\
$\mathrm{Cl}(2 \mathrm{~A})$ & $7773(6)$ & $5701(2)$ & $9726(2)$ & $49(1)$ \\
$\mathrm{C}(1 \mathrm{~B})$ & $7679(17)$ & $4767(8)$ & $9088(10)$ & $38(3)$ \\
$\mathrm{Cl}(1 \mathrm{~B})$ & $6847(9)$ & $3461(3)$ & $8820(4)$ & $70(1)$ \\
$\mathrm{Cl}(2 \mathrm{~B})$ & $6318(6)$ & $5610(2)$ & $9738(2)$ & $52(1)$ \\
\hline
\end{tabular}


Table S3. Bond Lengths ( $\AA$ ) for Mn(N)-SalophOMe

\begin{tabular}{llll}
\hline $\mathrm{Mn}(1)-\mathrm{N}(1)$ & $1.523(3)$ & $\mathrm{C}(8)-\mathrm{C}(13)$ & $1.443(5)$ \\
$\mathrm{Mn}(1)-\mathrm{O}(1)$ & $1.904(2)$ & $\mathrm{C}(9)-\mathrm{C}(10)$ & $1.379(5)$ \\
$\mathrm{Mn}(1)-\mathrm{O}(2)$ & $1.916(2)$ & $\mathrm{C}(9)-\mathrm{C}(27)$ & $1.545(5)$ \\
$\mathrm{Mn}(1)-\mathrm{N}(3)$ & $1.968(3)$ & $\mathrm{C}(10)-\mathrm{C}(11)$ & $1.419(5)$ \\
$\mathrm{Mn}(1)-\mathrm{N}(2)$ & $1.970(3)$ & $\mathrm{C}(11)-\mathrm{C}(12)$ & $1.367(5)$ \\
$\mathrm{N}(2)-\mathrm{C}(7)$ & $1.309(5)$ & $\mathrm{C}(12)-\mathrm{C}(13)$ & $1.426(5)$ \\
$\mathrm{N}(2)-\mathrm{C}(15)$ & $1.427(4)$ & $\mathrm{C}(13)-\mathrm{C}(14)$ & $1.420(5)$ \\
$\mathrm{N}(3)-\mathrm{C}(14)$ & $1.316(5)$ & $\mathrm{C}(15)-\mathrm{C}(20)$ & $1.405(5)$ \\
$\mathrm{N}(3)-\mathrm{C}(20)$ & $1.427(4)$ & $\mathrm{C}(15)-\mathrm{C}(16)$ & $1.407(5)$ \\
$\mathrm{O}(1)-\mathrm{C}(1)$ & $1.316(4)$ & $\mathrm{C}(16)-\mathrm{C}(17)$ & $1.392(5)$ \\
$\mathrm{O}(2)-\mathrm{C}(8)$ & $1.315(4)$ & $\mathrm{C}(17)-\mathrm{C}(18)$ & $1.380(5)$ \\
$\mathrm{O}(3)-\mathrm{C}(4)$ & $1.379(4)$ & $\mathrm{C}(18)-\mathrm{C}(19)$ & $1.385(5)$ \\
$\mathrm{O}(3)-\mathrm{C}(21)$ & $1.430(4)$ & $\mathrm{C}(19)-\mathrm{C}(20)$ & $1.404(5)$ \\
$\mathrm{O}(4)-\mathrm{C}(11)$ & $1.378(4)$ & $\mathrm{C}(23)-\mathrm{C}(24)$ & $1.539(5)$ \\
$\mathrm{O}(4)-\mathrm{C}(22)$ & $1.435(4)$ & $\mathrm{C}(23)-\mathrm{C}(26)$ & $1.543(5)$ \\
$\mathrm{C}(1)-\mathrm{C}(6)$ & $1.427(5)$ & $\mathrm{C}(23)-\mathrm{C}(25)$ & $1.558(5)$ \\
$\mathrm{C}(1)-\mathrm{C}(2)$ & $1.457(5)$ & $\mathrm{C}(27)-\mathrm{C}(28)$ & $1.534(6)$ \\
$\mathrm{C}(2)-\mathrm{C}(3)$ & $1.377(5)$ & $\mathrm{C}(27)-\mathrm{C}(29)$ & $1.539(5)$ \\
$\mathrm{C}(2)-\mathrm{C}(23)$ & $1.543(5)$ & $\mathrm{C}(27)-\mathrm{C}(30)$ & $1.552(5)$ \\
$\mathrm{C}(3)-\mathrm{C}(4)$ & $1.411(5)$ & $\mathrm{C}(1 \mathrm{~A})-\mathrm{Cl}(1 \mathrm{~A})$ & $1.766(11)$ \\
$\mathrm{C}(4)-\mathrm{C}(5)$ & $1.371(5)$ & $\mathrm{C}(1 \mathrm{~A})-\mathrm{Cl}(2 \mathrm{~A})$ & $1.778(10)$ \\
$\mathrm{C}(5)-\mathrm{C}(6)$ & $1.426(5)$ & $\mathrm{C}(1 \mathrm{~B})-\mathrm{Cl}(1 \mathrm{~B})$ & $1.740(12)$ \\
$\mathrm{C}(6)-\mathrm{C}(7)$ & $1.433(5)$ & $1.780(11)$ \\
$\mathrm{C}(8)-\mathrm{C}(9)$ & $1.439(5)$ & & \\
\hline & & & \\
& & & \\
\hline
\end{tabular}


Table S4. Bond Angles $\left({ }^{\circ}\right)$ for Mn(N)-SalophOMe

\begin{tabular}{|c|c|c|c|}
\hline $\mathrm{N}(1)-\mathrm{Mn}(1)-\mathrm{O}(1)$ & 108.99(13) & $\mathrm{C}(9)-\mathrm{C}(8)-\mathrm{C}(13)$ & $117.9(3)$ \\
\hline $\mathrm{N}(1)-\mathrm{Mn}(1)-\mathrm{O}(2)$ & $104.79(13)$ & $\mathrm{C}(10)-\mathrm{C}(9)-\mathrm{C}(8)$ & $118.3(3)$ \\
\hline $\mathrm{O}(1)-\mathrm{Mn}(1)-\mathrm{O}(2)$ & $82.66(10)$ & $\mathrm{C}(10)-\mathrm{C}(9)-\mathrm{C}(27)$ & $121.5(3)$ \\
\hline $\mathrm{N}(1)-\mathrm{Mn}(1)-\mathrm{N}(3)$ & $104.95(14)$ & $\mathrm{C}(8)-\mathrm{C}(9)-\mathrm{C}(27)$ & $120.0(3)$ \\
\hline $\mathrm{O}(1)-\mathrm{Mn}(1)-\mathrm{N}(3)$ & $146.00(12)$ & $\mathrm{C}(9)-\mathrm{C}(10)-\mathrm{C}(11)$ & $123.7(3)$ \\
\hline $\mathrm{O}(2)-\mathrm{Mn}(1)-\mathrm{N}(3)$ & $90.71(11)$ & $\mathrm{C}(12)-\mathrm{C}(11)-\mathrm{O}(4)$ & $126.4(3)$ \\
\hline $\mathrm{N}(1)-\mathrm{Mn}(1)-\mathrm{N}(2)$ & $101.58(14)$ & $\mathrm{C}(12)-\mathrm{C}(11)-\mathrm{C}(10)$ & 119.1(3) \\
\hline $\mathrm{O}(1)-\mathrm{Mn}(1)-\mathrm{N}(2)$ & $89.67(11)$ & $\mathrm{O}(4)-\mathrm{C}(11)-\mathrm{C}(10)$ & $114.4(3)$ \\
\hline $\mathrm{O}(2)-\mathrm{Mn}(1)-\mathrm{N}(2)$ & $153.62(12)$ & $\mathrm{C}(11)-\mathrm{C}(12)-\mathrm{C}(13)$ & $119.9(3)$ \\
\hline $\mathrm{N}(3)-\mathrm{Mn}(1)-\mathrm{N}(2)$ & $81.62(12)$ & $\mathrm{C}(14)-\mathrm{C}(13)-\mathrm{C}(12)$ & $117.2(3)$ \\
\hline$C(7)-N(2)-C(15)$ & $121.1(3)$ & $\mathrm{C}(14)-\mathrm{C}(13)-\mathrm{C}(8)$ & $121.9(3)$ \\
\hline $\mathrm{C}(7)-\mathrm{N}(2)-\mathrm{Mn}(1)$ & $125.5(2)$ & $C(12)-C(13)-C(8)$ & $120.8(3)$ \\
\hline C(15)-N(2)-Mn(1) & $113.2(2)$ & $\mathrm{N}(3)-\mathrm{C}(14)-\mathrm{C}(13)$ & $126.3(3)$ \\
\hline$C(14)-N(3)-C(20)$ & $121.0(3)$ & $\mathrm{C}(20)-\mathrm{C}(15)-\mathrm{C}(16)$ & $120.5(3)$ \\
\hline C(14)-N(3)-Mn(1) & $125.5(2)$ & $\mathrm{C}(20)-\mathrm{C}(15)-\mathrm{N}(2)$ & $114.3(3)$ \\
\hline $\mathrm{C}(20)-\mathrm{N}(3)-\mathrm{Mn}(1)$ & $113.4(2)$ & $\mathrm{C}(16)-\mathrm{C}(15)-\mathrm{N}(2)$ & $125.2(3)$ \\
\hline $\mathrm{C}(1)-\mathrm{O}(1)-\mathrm{Mn}(1)$ & $128.1(2)$ & $\mathrm{C}(17)-\mathrm{C}(16)-\mathrm{C}(15)$ & $118.6(3)$ \\
\hline $\mathrm{C}(8)-\mathrm{O}(2)-\mathrm{Mn}(1)$ & $127.8(2)$ & $\mathrm{C}(18)-\mathrm{C}(17)-\mathrm{C}(16)$ & $120.9(3)$ \\
\hline $\mathrm{C}(4)-\mathrm{O}(3)-\mathrm{C}(21)$ & $117.0(3)$ & $\mathrm{C}(17)-\mathrm{C}(18)-\mathrm{C}(19)$ & $121.0(3)$ \\
\hline $\mathrm{C}(11)-\mathrm{O}(4)-\mathrm{C}(22)$ & $116.6(3)$ & $\mathrm{C}(18)-\mathrm{C}(19)-\mathrm{C}(20)$ & $119.5(3)$ \\
\hline $\mathrm{O}(1)-\mathrm{C}(1)-\mathrm{C}(6)$ & $123.0(3)$ & $\mathrm{C}(19)-\mathrm{C}(20)-\mathrm{C}(15)$ & $119.5(3)$ \\
\hline $\mathrm{O}(1)-\mathrm{C}(1)-\mathrm{C}(2)$ & $119.5(3)$ & $\mathrm{C}(19)-\mathrm{C}(20)-\mathrm{N}(3)$ & $126.4(3)$ \\
\hline$C(6)-C(1)-C(2)$ & $117.4(3)$ & $\mathrm{C}(15)-\mathrm{C}(20)-\mathrm{N}(3)$ & $114.1(3)$ \\
\hline$C(3)-C(2)-C(1)$ & $118.1(3)$ & $C(24)-C(23)-C(2)$ & $109.6(3)$ \\
\hline$C(3)-C(2)-C(23)$ & $121.8(3)$ & $\mathrm{C}(24)-\mathrm{C}(23)-\mathrm{C}(26)$ & $107.6(3)$ \\
\hline$C(1)-C(2)-C(23)$ & 120.1(3) & $C(2)-C(23)-C(26)$ & $111.2(3)$ \\
\hline$C(2)-C(3)-C(4)$ & $123.8(3)$ & $C(24)-C(23)-C(25)$ & $110.9(3)$ \\
\hline $\mathrm{C}(5)-\mathrm{C}(4)-\mathrm{O}(3)$ & $125.8(3)$ & $\mathrm{C}(2)-\mathrm{C}(23)-\mathrm{C}(25)$ & $109.8(3)$ \\
\hline$C(5)-C(4)-C(3)$ & $119.4(3)$ & $\mathrm{C}(26)-\mathrm{C}(23)-\mathrm{C}(25)$ & $107.7(3)$ \\
\hline $\mathrm{O}(3)-\mathrm{C}(4)-\mathrm{C}(3)$ & $114.8(3)$ & $\mathrm{C}(28)-\mathrm{C}(27)-\mathrm{C}(29)$ & $107.9(3)$ \\
\hline$C(4)-C(5)-C(6)$ & $119.3(3)$ & $\mathrm{C}(28)-\mathrm{C}(27)-\mathrm{C}(9)$ & $109.2(3)$ \\
\hline$C(5)-C(6)-C(1)$ & $121.8(3)$ & $\mathrm{C}(29)-\mathrm{C}(27)-\mathrm{C}(9)$ & $111.4(3)$ \\
\hline$C(5)-C(6)-C(7)$ & $116.7(3)$ & $\mathrm{C}(28)-\mathrm{C}(27)-\mathrm{C}(30)$ & $109.8(3)$ \\
\hline
\end{tabular}




\begin{tabular}{llll}
$\mathrm{C}(1)-\mathrm{C}(6)-\mathrm{C}(7)$ & $121.3(3)$ & $\mathrm{C}(29)-\mathrm{C}(27)-\mathrm{C}(30)$ & $107.7(3)$ \\
$\mathrm{N}(2)-\mathrm{C}(7)-\mathrm{C}(6)$ & $125.5(3)$ & $\mathrm{C}(9)-\mathrm{C}(27)-\mathrm{C}(30)$ & $110.8(3)$ \\
$\mathrm{O}(2)-\mathrm{C}(8)-\mathrm{C}(9)$ & $120.2(3)$ & $\mathrm{Cl}(1 \mathrm{~A})-\mathrm{C}(1 \mathrm{~A})-\mathrm{Cl}(2 \mathrm{~A})$ & $112.1(6)$ \\
$\mathrm{O}(2)-\mathrm{C}(8)-\mathrm{C}(13)$ & $121.8(3)$ & $\mathrm{Cl}(2 \mathrm{~B})-\mathrm{C}(1 \mathrm{~B})-\mathrm{Cl}(1 \mathrm{~B})$ & $112.8(7)$ \\
\hline
\end{tabular}


Table S5. Anisotropic displacement parameters $\left(\AA^{2} \times 10^{3}\right)$ for Mn(N)-SalophOMe. The anisotropic displacement factor exponent takes the form: $2 \pi^{2}\left[h^{2} a^{* 2} U_{11}+\ldots+2 h k a * b * U_{12}\right]$.

\begin{tabular}{|c|c|c|c|c|c|c|}
\hline Atom & $\mathrm{U}_{11}$ & $\mathrm{U}_{22}$ & $\mathrm{U}_{33}$ & $\mathrm{U}_{23}$ & $\mathrm{U}_{13}$ & $\mathrm{U}_{12}$ \\
\hline $\operatorname{Mn}(1)$ & $18(1)$ & $13(1)$ & $18(1)$ & $9(1)$ & $1(1)$ & $5(1)$ \\
\hline $\mathrm{N}(1)$ & $23(2)$ & $16(2)$ & $25(2)$ & $11(1)$ & $3(1)$ & $5(1)$ \\
\hline $\mathrm{N}(2)$ & $21(2)$ & $17(2)$ & $20(2)$ & $12(1)$ & $4(1)$ & $7(1)$ \\
\hline $\mathrm{N}(3)$ & $15(2)$ & $16(2)$ & $22(2)$ & $11(1)$ & $-1(1)$ & $4(1)$ \\
\hline $\mathrm{O}(1)$ & $23(1)$ & $14(1)$ & $18(1)$ & $6(1)$ & $-2(1)$ & $5(1)$ \\
\hline $\mathrm{O}(2)$ & $21(1)$ & $17(1)$ & $18(1)$ & $10(1)$ & $1(1)$ & $7(1)$ \\
\hline $\mathrm{O}(3)$ & $28(2)$ & $17(1)$ & $21(1)$ & $5(1)$ & $-3(1)$ & $7(1)$ \\
\hline $\mathrm{O}(4)$ & $37(2)$ & $19(1)$ & $18(1)$ & $8(1)$ & $-3(1)$ & $9(1)$ \\
\hline $\mathrm{C}(1)$ & $17(2)$ & $18(2)$ & $23(2)$ & $11(2)$ & $5(2)$ & $6(2)$ \\
\hline $\mathrm{C}(2)$ & $18(2)$ & $15(2)$ & $19(2)$ & $9(2)$ & $2(2)$ & $4(2)$ \\
\hline$C(3)$ & $22(2)$ & $19(2)$ & $20(2)$ & $12(2)$ & $2(2)$ & $6(2)$ \\
\hline $\mathrm{C}(4)$ & $16(2)$ & $16(2)$ & $19(2)$ & $5(2)$ & $2(2)$ & $4(2)$ \\
\hline$C(5)$ & $20(2)$ & $15(2)$ & $24(2)$ & $11(2)$ & $2(2)$ & $5(2)$ \\
\hline$C(6)$ & $18(2)$ & $16(2)$ & $21(2)$ & $10(2)$ & $2(2)$ & $4(2)$ \\
\hline$C(7)$ & $20(2)$ & $13(2)$ & $22(2)$ & $8(2)$ & $6(2)$ & $5(2)$ \\
\hline $\mathrm{C}(8)$ & $16(2)$ & $16(2)$ & $19(2)$ & $7(2)$ & $3(2)$ & $6(2)$ \\
\hline $\mathrm{C}(9)$ & $20(2)$ & $14(2)$ & $21(2)$ & $9(2)$ & $2(2)$ & $6(2)$ \\
\hline$C(10)$ & $25(2)$ & $15(2)$ & $27(2)$ & $11(2)$ & $5(2)$ & $6(2)$ \\
\hline $\mathrm{C}(11)$ & $18(2)$ & $21(2)$ & $18(2)$ & $6(2)$ & $2(2)$ & $7(2)$ \\
\hline$C(12)$ & $16(2)$ & $20(2)$ & $22(2)$ & $13(2)$ & $3(2)$ & $6(2)$ \\
\hline$C(13)$ & $16(2)$ & $19(2)$ & $21(2)$ & $12(2)$ & $4(2)$ & $6(2)$ \\
\hline$C(14)$ & $15(2)$ & $22(2)$ & $20(2)$ & $12(2)$ & $2(2)$ & $6(2)$ \\
\hline$C(15)$ & $18(2)$ & $17(2)$ & $25(2)$ & $13(2)$ & $4(2)$ & $5(2)$ \\
\hline$C(16)$ & $23(2)$ & $15(2)$ & $22(2)$ & $9(2)$ & $3(2)$ & $4(2)$ \\
\hline$C(17)$ & $28(2)$ & $16(2)$ & $31(2)$ & $14(2)$ & $4(2)$ & $6(2)$ \\
\hline$C(18)$ & $36(2)$ & $22(2)$ & $27(2)$ & $18(2)$ & $-1(2)$ & $7(2)$ \\
\hline$C(19)$ & $30(2)$ & $21(2)$ & $22(2)$ & $11(2)$ & $-2(2)$ & $3(2)$ \\
\hline$C(20)$ & $20(2)$ & $16(2)$ & $24(2)$ & $11(2)$ & $4(2)$ & $5(2)$ \\
\hline$C(21)$ & $26(2)$ & $18(2)$ & $27(2)$ & $6(2)$ & $2(2)$ & $4(2)$ \\
\hline$C(22)$ & $30(2)$ & $25(2)$ & $18(2)$ & $11(2)$ & $0(2)$ & $7(2)$ \\
\hline$C(23)$ & $26(2)$ & $15(2)$ & $19(2)$ & $10(2)$ & $-1(2)$ & $5(2)$ \\
\hline
\end{tabular}




\begin{tabular}{rrrrrrr}
$\mathrm{C}(24)$ & $27(2)$ & $17(2)$ & $28(2)$ & $11(2)$ & $5(2)$ & $10(2)$ \\
$\mathrm{C}(25)$ & $28(2)$ & $19(2)$ & $21(2)$ & $10(2)$ & $0(2)$ & $3(2)$ \\
$\mathrm{C}(26)$ & $33(2)$ & $20(2)$ & $27(2)$ & $13(2)$ & $-2(2)$ & $9(2)$ \\
$\mathrm{C}(27)$ & $32(2)$ & $16(2)$ & $21(2)$ & $12(2)$ & $-4(2)$ & $1(2)$ \\
$\mathrm{C}(28)$ & $37(2)$ & $31(2)$ & $27(2)$ & $21(2)$ & $2(2)$ & $0(2)$ \\
$\mathrm{C}(29)$ & $56(3)$ & $21(2)$ & $33(2)$ & $17(2)$ & $-8(2)$ & $1(2)$ \\
$\mathrm{C}(30)$ & $38(2)$ & $24(2)$ & $28(2)$ & $16(2)$ & $-2(2)$ & $13(2)$ \\
$\mathrm{C}(1 \mathrm{~A})$ & $41(8)$ & $21(6)$ & $33(8)$ & $2(5)$ & $-2(6)$ & $1(5)$ \\
$\mathrm{Cl}(1 \mathrm{~A})$ & $58(2)$ & $41(2)$ & $45(2)$ & $20(2)$ & $8(2)$ & $16(2)$ \\
$\mathrm{Cl}(2 \mathrm{~A})$ & $64(3)$ & $42(2)$ & $31(1)$ & $10(1)$ & $1(1)$ & $12(1)$ \\
$\mathrm{C}(1 \mathrm{~B})$ & $34(8)$ & $31(8)$ & $35(8)$ & $3(6)$ & $2(6)$ & $2(6)$ \\
$\mathrm{Cl}(1 \mathrm{~B})$ & $81(3)$ & $49(2)$ & $72(3)$ & $26(2)$ & $2(2)$ & $1(2)$ \\
$\mathrm{Cl}(2 \mathrm{~B})$ & $57(3)$ & $64(2)$ & $34(1)$ & $19(1)$ & $5(1)$ & $23(2)$ \\
\hline
\end{tabular}


Table S6. Hydrogen Coordinates $\left(\times 10^{4}\right)$ and Isotropic Displacement Parameters $\left(\AA^{2} \times 10^{3}\right)$ for Mn(N)-SalophOMe

\begin{tabular}{|c|c|c|c|c|}
\hline Atom & $\mathrm{x}$ & $\mathrm{y}$ & $\mathrm{z}$ & $\mathrm{U}(\mathrm{eq})$ \\
\hline $\mathrm{H}(3)$ & 5552 & 3529 & 6796 & 23 \\
\hline $\mathrm{H}(5)$ & 3980 & 5860 & 6242 & 23 \\
\hline $\mathrm{H}(7)$ & 2348 & 5534 & 4774 & 21 \\
\hline $\mathrm{H}(10)$ & -2538 & -1634 & 341 & 26 \\
\hline $\mathrm{H}(12)$ & -2621 & 792 & -289 & 21 \\
\hline $\mathrm{H}(14)$ & -1450 & 2463 & 838 & 22 \\
\hline $\mathrm{H}(16)$ & 948 & 6281 & 4096 & 24 \\
\hline $\mathrm{H}(17)$ & -440 & 6869 & 3045 & 28 \\
\hline $\mathrm{H}(18)$ & -1976 & 5720 & 1580 & 32 \\
\hline $\mathrm{H}(19)$ & -2192 & 3954 & 1118 & 29 \\
\hline $\mathrm{H}(21 \mathrm{~A})$ & 6568 & 6745 & 7465 & 38 \\
\hline $\mathrm{H}(21 \mathrm{~B})$ & 6657 & 6858 & 8488 & 38 \\
\hline $\mathrm{H}(21 \mathrm{C})$ & 4649 & 6661 & 7830 & 38 \\
\hline $\mathrm{H}(22 \mathrm{~A})$ & -4995 & -397 & -1455 & 36 \\
\hline $\mathrm{H}(22 \mathrm{~B})$ & -4747 & -1466 & -2242 & 36 \\
\hline $\mathrm{H}(22 \mathrm{C})$ & -2996 & -543 & -1764 & 36 \\
\hline $\mathrm{H}(24 \mathrm{~A})$ & 4952 & 696 & 4191 & 35 \\
\hline $\mathrm{H}(24 \mathrm{~B})$ & 6263 & 1787 & 4542 & 35 \\
\hline $\mathrm{H}(24 \mathrm{C})$ & 4224 & 1552 & 3897 & 35 \\
\hline $\mathrm{H}(25 \mathrm{~A})$ & 1214 & 1338 & 4554 & 34 \\
\hline $\mathrm{H}(25 \mathrm{~B})$ & 1485 & 1526 & 5604 & 34 \\
\hline $\mathrm{H}(25 \mathrm{C})$ & 2085 & 525 & 4867 & 34 \\
\hline $\mathrm{H}(26 \mathrm{~A})$ & 5320 & 948 & 5808 & 39 \\
\hline $\mathrm{H}(26 \mathrm{~B})$ & 4734 & 1940 & 6562 & 39 \\
\hline $\mathrm{H}(26 \mathrm{C})$ & 6573 & 2053 & 6148 & 39 \\
\hline $\mathrm{H}(28 \mathrm{~A})$ & -1949 & -500 & 3375 & 44 \\
\hline $\mathrm{H}(28 \mathrm{~B})$ & -3534 & -367 & 2654 & 44 \\
\hline $\mathrm{H}(28 \mathrm{C})$ & -1721 & 509 & 3196 & 44 \\
\hline $\mathrm{H}(29 \mathrm{~A})$ & -1192 & -2285 & 1221 & 56 \\
\hline $\mathrm{H}(29 \mathrm{~B})$ & -3230 & -2037 & 1442 & 56 \\
\hline $\mathrm{H}(29 \mathrm{C})$ & -1698 & -2186 & 2174 & 56 \\
\hline
\end{tabular}




\begin{tabular}{llrll}
$\mathrm{H}(30 \mathrm{~A})$ & 1718 & -961 & 2066 & 43 \\
$\mathrm{H}(30 \mathrm{~B})$ & 1193 & -929 & 2995 & 43 \\
$\mathrm{H}(30 \mathrm{C})$ & 1553 & 112 & 2874 & 43 \\
$\mathrm{H}(1 \mathrm{~A} 1)$ & 5604 & 4343 & 8626 & 44 \\
$\mathrm{H}(1 \mathrm{~A} 2)$ & 7541 & 4424 & 8274 & 44 \\
$\mathrm{H}(1 \mathrm{~B} 1)$ & 9007 & 4954 & 9430 & 46 \\
$\mathrm{H}(1 \mathrm{~B} 2)$ & 7669 & 4842 & 8511 & 46 \\
\hline
\end{tabular}

